\title{
PENGARUH TINDAKAN KONSERVASI TANAH DAN APLIKASI PUPUK ORGANONITROFOS TERHADAP KEHILANGAN UNSUR HARA DAN BAHAN ORGANIK PADA FASE GENERATIF PERTANAMAN SINGKONG (Manihot esculenta Crantz.) DI LABORATORIUM LAPANG TERPADU FAKULTAS PERTANIAN UNIVERSITAS LAMPUNG
}

\section{THE EFFECT OF SOIL CONSERVATION AND APPLICATION OF ORGANO- NITROFOS FERTILIZERS ON NUTRIENT AND ORGANIC MATERIAL LOSSES IN THE GENERATIVE PHASE OF CASSAVA CROPPING (Manihot esculenta Crantz.) AT INTEGRATED FIELD LABORATORY FACULTY OF AGRICULTUREUNIVERSITY OF LAMPUNG}

\author{
Libero Tri Buana*, Irwan Sukri Banuwa, Kuswanta Futas Hidayat, dan Afandi \\ Jurusan Agroteknologi, Fakultas Pertanian, Universitas Lampung \\ J1 Sumantri Brojonegoro 1, Bandar Lampung 35145, Indonesia \\ *Email: liberotribuana@gmail.com
}

\section{ABSTRACT}

Soil conservation is the placement of each parcel of land in a manner that is appropriate to the ability of the land and treats it with the necessary conditions to prevent soil damage.In general, the purpose of soil conservation is to increase land productivity and make efforts to prevent soil damage due to erosion. This research was conducted in May 2018 until July 2018 at Integrated Field Laboratory and Soil Science Laboratory, Faculty of Agriculture, University of Lampung. This study aims to determine the effect of soil conservation measures on the amount of nutrient loss and organic matter in cassava plantations. The design used in this study was a Complete Randomized Block Design with two treatment factors, namely to plant with mounds and application of organonitrofos fertilizer with four replications. The results of the analysis of variance showed that the application of organonitrofos fertilizer did not significantly affect the loss of $N$-total, $P$-available, $K$-dd and $C$-organic, while there was no interaction between the application of soil conservation measures and the application of organonitrofos fertilizer.

Keywords: Erosion, organonitrofos fertilizer, soil conservation.

\begin{abstract}
ABSTRAK
Konservasi tanah adalah penempatan tiap bidang tanah pada cara penggunaan yang sesuai dengan kemampuan tanah dan memperlakukannya dengan syarat-syarat yang diperlukan agar tidak terjadi kerusakan tanah. Secara umum tujuan konservasi tanah adalah meningkatkan produktivitas lahan dan melakukan upaya pencegahan kerusakan tanah akibat erosi. Penelitian ini dilaksanakan pada Mei 2018 sampai Juli 2018 di Laboratorium Lapang Terpadu dan Laboratorium Ilmu Tanah, Fakultas Pertanian, Universitas Lampung. Penelitian ini bertujuan untuk mengetahui pengaruh tindakan konservasi tanah terhadap besarnya kehilangan unsur hara dan bahan organik pada lahan pertanaman singkong. Rancangan yang digunakan dakam penelitian ini yaitu Rancangan Acak Kelompok Lengkap dengan dua faktor perlakuan yaitu cara penanaman dengan guludan dan aplikasi pupuk
\end{abstract}


organonitrofos dengan empat kali ulangan. Hasil analisis ragam menunjukkan bahwa aplikasi pupuk organonitrofos tidak berpengaruh nyata terhadap kehilangan N-total, P-tersedia, K-dd dan C-organik, sedangkan antara penerapan tindakan konservasi tanah dan aplikasi pupuk organonitrofos tidak ada interaksi.

Kata kunci: Erosi, konservasi tanah, pupuk organonitrofos.

\section{PENDAHULUAN}

Singkong merupakan tanaman pangan yang berasal dari Benua Amerika berupa perdu, memiliki nama lain singkong, kasepe dan dalam Bahasa Inggris cassava. Umbi singkong dapat dimanfaatkan sebagai sumber karbohidrat dan daunnya dikonsumsi sebagai sayuran. Di Indonesia, singkong menjadi bahan pangan pokok setelah beras dan jagung (Lidiasari etal., 2006).

Aplikasi bahan pembenah tanah (soil conditioner) dalam bentuk pupuk organik dilakukan untuk mengurangi terjadinya erosi. Menurut Lingga dan Marsono (1999), pemberian pupuk organik dapat memperbaiki struktur tanah sehingga tanah lebih tahan terhadap kerusakan akibat pukulan air hujan sehingga mampu mengurangi erosi. Selain itu, pemupukan memberikan tambahan unsur hara bagi tanaman agar kebutuhan unsur hara selama pertumbuhannya dapat tercukupi. Salah satu jenis pupuk organik yang dapat menyediakan unsur hara $\mathrm{N}$ dan Pyang cukup tinggi yaitu pupuk organonitrofos. Pupuk organonitrofos merupakan salah satu bentuk pupuk organik yang berasal dari $70-80 \%$ kotoran sapi dan $20-30 \%$ batuan fosfat, dengan penambahan mikroba penambat $\mathrm{N}$ dan pelarut P (Nugroho et al., 2012).

Penelitian ini bertujuan untukmengetahui pengaruh tindakan konservasi tanah terhadap besarnya kehilangan unsur hara $(\mathrm{N}, \mathrm{P}, \mathrm{K})$ dan bahan organik pada lahan petanaman singkong dan mempelajari pengaruh interaksi antara tindakan konservasi tanah dan aplikasi pupuk organonitrofos.

\section{BAHAN DAN METODE}

Penelitian ini dilaksanakan mulaiMei 2018 sampaiAgustus 2018 di Laboratorium Lapang Terpadu dan Laboratorium Ilmu Tanah, Fakultas Pertanian Universitas Lampung.

Pengukuran erosi dilakukan dengan cara mengukur erosi untuk satu kejadianhujan pada petak-petak kecil (multislot deviser). Penelitian ini dirancang dengan menggunakan rancangan faktorial (2x2) dalam Rancangan Acak Kelompok Lengkap (RAKL) dengan empat ulangan. Faktor pertama adalah cara penanaman, yang terdiri dari G1 (guludan searah lereng) dan G2 (guludan memotong lereng) dan faktor kedua adalah aplikasi pupuk organonitrofos yaitu P0 (tanpa aplikasi pupuk organonitrofos atau 0 ton/ha) dan P1 (aplikasi pupuk organonitrofos sebanyak 20 ton/ha). Berdasarkan kedua faktor perlakuan ini, maka diperoleh empat kombinasi perlakuan yaitu G1P0 (Guludan searah lereng + tanpa aplikasi pupuk organonitrofos 0 ton/ ha), G1P1 (Guludan searah lereng + aplikasi pupuk organonitrofos 20 ton/ha), G2P0 (Guludan memotong lereng + tanpa aplikasi pupuk organonitrofos 0 ton/ha), G2P1 (Guludan memotong lereng + aplikasi pupuk organonitrofos 20 ton/ha) 
Dilakukan empat kali pengulangan untuk setiap perlakuan sehingga didapatkan 16 satuan percobaan, dimana setiap satuan percobaannya ditempatkan pada petak erosi berukuran $4 \mathrm{~m} \times 4 \mathrm{~m}$.

\section{HASIL DAN PEMBAHASAN}

Kandungan Unsur Hara dan C-Organik di dalam Sedimen.

Hasil analisis ragam menunjukkan bahwa tindakan konservasi tanah berupa perlakuan guludan hanya memberikan pengaruh yang nyata terhadap kandungan K-dd pada sedimen. UjiBNT menunjukkan bahwa kandungan K-dd di dalam sedimen yang berasal dari petak erosi dengan perlakuan guludan searah lereng berbeda nyata dibandingkan perlakuan guludan memotong lereng. Kandungan K-dd dalam sedimen pada perlakuan guludan searah lereng nyata lebih rendah dibandingkan pada perlakuan guludan memotong lereng. Hasil ini didukung oleh penelitian Henny dkk. (2011) yang menunjukkan bahwa kandungan N-total, Ptersedia, K-dd, dan C-organik di dalam sedimen pada lahan pertanaman kentang dengan perlakuan guludan searah lereng nyata lebih rendah dibandingkan pada perlakuan guludan memotong lereng.

Kandungan K-dd di dalam sedimen yang berbeda nyata tersebut disebabkan karena laju aliran permukaan yang berbeda nyata pada kedua perlakuan guludan. Aliran permukaan yang lebih kecil pada guludan memotong lereng menyebabkan K-dd sedimen guludan memotong lereng lebih banyak dari pada Kdd sedimen di guludan searah lereng. Penelitian Sutapradja dan Asandhi (1998) menunjukkan bahwa penanaman di atas guludan searah lereng pada lahan pertanaman kentang menghasilkan laju aliran permukaan yang lebih tinggi dibandingkan dengan penanaman di atas guludan memotong lereng.

Sifat unsur hara sendiri mempengaruhi mudah atau tidaknya unsur tersebut tercuci oleh aliran permukaan erosi. Unsur hara yang mudah larut dalam air akan terangkut bersama aliran permukaan dan unsur hara yang ada pada bagian partikel tanah akan terangkut bersama erosi dan diendapkan sebagai sedimen (Pratiwi dan Narendra, 2012). Unsur K merupakan unsur hara yang mudah tercuci dan tererosi. Menurut Soepardi (1983), kehilangan unsur hara K yang paling besar terjadi melalui erosi.

Tabel 1. Pengaruh Tindakan Konservasi Tanah dan Aplikasi Pupuk Organonitrofos terhadap N-total, P-tersedia, K-dd dan C-organik dalam Sedimen.

\begin{tabular}{cccccc}
\hline \multirow{2}{*}{ Perlakuan } & N-total & \multicolumn{2}{c}{ P-tersedia $(\mathrm{ppm})$} & K-dd & \multicolumn{2}{c}{ C-organik } \\
\cline { 2 - 6 } & $(\%)$ & Asli & Transformasi $\sqrt{\mathrm{x}}$ & $(\mathrm{me} / 100 \mathrm{~g})$ & $(\%)$ \\
\hline G1 & $0,20 \mathrm{a}$ & $27,32 \mathrm{a}$ & $2,22 \mathrm{a}$ & $0,67 \mathrm{a}$ & $2,11 \mathrm{a}$ \\
G2 & $0,20 \mathrm{a}$ & $29,63 \mathrm{a}$ & $2,17 \mathrm{a}$ & $0,85 \mathrm{~b}$ & $2,17 \mathrm{a}$ \\
\hline Nilai BNT 5\% & 0,07 & & 0,37 & 0,14 & 0,59 \\
\hline P0 & $0,21 \mathrm{a}$ & $37,06 \mathrm{a}$ & $2,34 \mathrm{a}$ & $0,76 \mathrm{a}$ & $2,16 \mathrm{a}$ \\
P1 & $0,19 \mathrm{a}$ & $19,89 \mathrm{a}$ & $2,05 \mathrm{a}$ & $0,76 \mathrm{a}$ & $2,12 \mathrm{a}$ \\
\hline Nilai BNT 5\% & 0,07 & & 0,37 & 0,14 & 0,59 \\
\hline
\end{tabular}


Hasil uji BNT menunjukkan bahwa aplikasi pupuk organonitrofos pada lahan pertanaman singkong tidak memberikan pengaruh nyata terhadap kandungan N-total, P-tersedia, K-dd, dan C-organik di dalam sedimen (Tabel 1). Hasil ini menunjukkan bahwa aplikasi pupuk organonitrofos belum mampumenekan erosi karena kandungan unsur hara dan C-organik dalam sedimen baik dengan pemupukan 20 ton/ha atau tanpa pupuk tidak berbeda nyata.

\section{Nisbah Pengayaan}

Nisbah pengayaan didapatkan melalui perhitungan dengan membandingkan konsentrasi unsur hara pada sedimen yang tererosi dengan tanah asalnya (Sinukaban, 1981dalam Banuwa, 1994).Hasil analisis ragam menunjukkan bahwa perlakuan tindakan konservasi tanah berupa guludan dan pemberian pupuk tidak berpengaruh nyata terhadap nisbah pengayaan $\mathrm{N}$-total dan P-tersedia, K-dd, dan C-organik.

Nilai dari nisbah pengayaan adalah perbandingan antara kandungan hara dalam sedimen dibagi dengan kandungan hara pada tanah asalnya. Jika nilai nisbah lebih dari 1,00 artinya kandungan hara pada sedimen lebih tinggi dibandingkan tanah asalnya. Jika nilai nisbah dibawah 1,00 artinya kandungan hara pada sedimen lebih sedikit dibandingkan tanah asalnya.

Nilai dari nisbah pengayaan adalah perbandingan antara kandungan hara dalam sedimen dibagi dengan kandungan hara pada tanah asalnya. Jika nilai nisbah lebih dari 1,00 artinya kandungan hara pada sedimen lebih tinggi dibandingkan tanah asalnya. Jika nilai nisbah dibawah 1,00 artinya kandungan hara pada sedimen lebih sedikit dibandingkan tanah asalnya, sehingga tindakan konservasi tanah dan aplikasi pupuk organonitrofos tidak berpengaruh nyata terhadap pengayaan N-total, P-tersedia, K-dd, dan C-organik.

Berdasarkan data curah hujan pada penelitian ini, dari 6 hari hujan yang terjadi selama penelitian, jumlahnya adalah $42,45 \mathrm{~mm}$, dengan rata-rata 7,07 $\mathrm{mm}$ per hari. Perlakuan guludan di penelitian ini berpengaruh nyata terhadap aliran permukaan yang terjadi pada lahan pertanaman singkong. Aliran permukaan pada guludan yang searah lereng lebih tinggi dibandingkan guludan yang memotong lereng. Namun perlakuan guludan dan pemupukan tidak berpengaruh terhadap erosi yang terjadi karena tidak memberikan pengaruh yang nyata.

\section{Kehilangan Unsur Hara dan C-Organik}

MenurutBanuwa(2013), erosi akan memberikan

Tabel 2. Nisbah Pengayaan N-Total,P-Tersedia, K-dd, dan C-Organik.

\begin{tabular}{ccccccc}
\hline \multirow{2}{*}{ Perlakuan } & \multicolumn{2}{c}{ N-total } & \multicolumn{2}{c}{ P-tersedia } & \multirow{2}{*}{ K-dd } & C-organik \\
\cline { 2 - 6 } & Asli & Transformasi $\sqrt{\mathrm{x}}$ & Asli & Transformasi $\sqrt{\mathrm{x}}$ & & \\
\hline G1 & 1,31 & $1,13 \mathrm{a}$ & $0,43 \mathrm{a}$ & $0,79 \mathrm{a}$ & $1,79 \mathrm{a}$ & $1,64 \mathrm{a}$ \\
G2 & 1,44 & $1,19 \mathrm{a}$ & $0,68 \mathrm{a}$ & $0,83 \mathrm{a}$ & $2,12 \mathrm{a}$ & $1,64 \mathrm{a}$ \\
\hline Nilai BNT 5\% & & 0,21 & & 0,15 & 0,59 & 0,51 \\
\hline P0 & 1,44 & $1,19 \mathrm{a}$ & $0,77 \mathrm{a}$ & 0,87 & $1,97 \mathrm{a}$ & $1,67 \mathrm{a}$ \\
P1 & 1,31 & $1,14 \mathrm{a}$ & $0,34 \mathrm{a}$ & 0,75 & $1,94 \mathrm{a}$ & $1,60 \mathrm{a}$ \\
\hline Nilai BNT 5\% & & 0,21 & 0,15 & 0,59 & 0,51 \\
\hline
\end{tabular}


dampak di tempat terjadinya erosi (on site) dan di luar tempat kejadian erosi (off site). Erosi pada di luar tempat kejadian akan menyebabkan sedimen, sedangkan pada tempat terjadinya erosi akan kehilangan lapisan tanah dan unsur hara.Besarnya unsur hara yang hilang dari tanah yang tererosi tergantung terhadap banyaknya unsur hara yang terbawa erosi serta besarnya erosi yang terjadi. Semakin besar erosi yang terjadi maka akan semakin besar kehilangan unsur hara dan bahan organik pada tanah tersebut. Kehilangan unsur hara yang terbawa erosi dapat diperoleh dengan mengalikan kandungan unsur hara dalam sedimen dengan banyaknya tanah yang tererosi (Banuwa, 2013). Besarnya unsur hara dan bahan organik yang hilang akibaterosipada penelitian ini disajikan pada Tabel3.

Tabel 3 menunjukkan bahwa hara yang terangkut pada variabel N-total, P-tersedia, K-dd, dan Corganik yang hilang akibaterosi tidak berbeda nyata menurut Uji BNT taraf 5\%. Hal ini terjadi karena erosi yang dihasilkan tidak berbeda nyata. Erosi yang tidak berbeda nyata tersebut menyebabkan hara yang terangkut pada sedimen juga tidak berbeda nyata.
Besarnya kehilangan N-total, P-tersedia, K-dd, dan C-organik akibat erosi secara berturut-turut pada perlakuan guludan memotong lereng sebesar $0,08 \mathrm{~kg} /$ ha, 1,38 g/ha, 13,47 g/ha, dan 0,86 kg/ha, sedangkan pada perlakuan guludan searah lereng adalah sebesar $0,10 \mathrm{~kg} / \mathrm{ha}, 1,59 \mathrm{~g} / \mathrm{ha}, 13,81 \mathrm{~g} / \mathrm{ha}$, dan $1,07 \mathrm{~kg} / \mathrm{ha}$. Hasil penelitian Banuwa (1994) menunjukkan bahwa guludan memotong lereng dapat menekan aliran permukaan dan erosi karena adanya guludan yang cukup rapat pada setiap barisan tanaman sehingga volume dan kecepatan aliran permukaan berkurang dan kapasitas transportasinya menjadi rendah sehingga erosi juga rendah.

Kandungan N-total, P-tersedia, K-dd, dan Corganik yang hilang akibat erosi pada perlakuan pupuk organonitrofos 20 ton/ha tidak berbeda nyata dengan perlakuan tanpa pupuk organonitrofos 0 ton/ha. Besarnya kehilangan N-total, P-tersedia, K-dd, dan C-organik akibat erosi secara berturut-turut pada perlakuan tanpa aplikasi pupuk organonitrofos 0 ton/ ha adalah sebesar $0,08 \mathrm{~kg} / \mathrm{ha}, 2,04 \mathrm{~g} / \mathrm{ha}, 12,46 \mathrm{~g} / \mathrm{ha}$, dan $0,90 \mathrm{~kg} / \mathrm{ha}$, sedangkan pada perlakuan aplikasi

Tabel 3. Kehilangan Unsur Hara N-Total, P-tersedia, K-dd dan C-organikAkibat Erosi(Kandungan dalam Sedimen).

\begin{tabular}{ccccccc}
\hline \multirow{2}{*}{ Perlakuan } & \multicolumn{5}{c}{ Unsur Hara yang Terangkut } \\
\cline { 2 - 6 } & Asli & Transformasi $\sqrt{\mathrm{x}}$ & Asli & Transformasi $\sqrt{\mathrm{x}}$ & $\mathrm{K}(\mathrm{g} / \mathrm{ha})$ & $\mathrm{C}(\mathrm{kg} / \mathrm{ha})$ \\
\hline G1 & 0,10 & $0,31 \mathrm{a}$ & $1,59 \mathrm{a}$ & $1,05 \mathrm{a}$ & $13,81 \mathrm{a}$ & $1,07 \mathrm{a}$ \\
$\mathrm{G} 2$ & 0,08 & $0,28 \mathrm{a}$ & $1,38 \mathrm{a}$ & $0,95 \mathrm{a}$ & $13,47 \mathrm{a}$ & $0,86 \mathrm{a}$ \\
\hline Nilai BNT 5\% & 0,05 & 0,08 & 0,30 & 7,48 & 0,50 \\
\hline P0 & 0,08 & $0,28 \mathrm{a}$ & $2,04 \mathrm{a}$ & $1,05 \mathrm{a}$ & $12,46 \mathrm{a}$ & $0,90 \mathrm{a}$ \\
P1 & 0,10 & $0,30 \mathrm{a}$ & $0,93 \mathrm{a}$ & $0,95 \mathrm{a}$ & $14,81 \mathrm{a}$ & $1,03 \mathrm{a}$ \\
\hline Nilai BNT 5\% & 0,05 & 0,08 & & 0,30 & 7,48 & 0,50 \\
\hline
\end{tabular}

Keterangan : Angka-angka yang diikuti huruf yang sama, tidak berbeda pada taraf nyata 5\% menurut Uji Beda Nyata Terkecil; G1 : Guludan searah lereng, G2 : Guludan memotong lereng, P0 : Tanpa aplikasi pupuk organonitrofos 0 ton/ha, P1 : Aplikasi pupuk organonitrofos 20 ton/ha 
pupuk organonitrofos 20 ton/ha sebesar $0,10 \mathrm{~kg} / \mathrm{ha}$, $0,93 \mathrm{~g} / \mathrm{ha}, 14,81 \mathrm{~g} / \mathrm{ha}$, dan 1,03 kg/ha.

\section{KESIMPULAN}

Kesimpulan yang dapat diambil dari penelitian ini adalah penerapan tindakan konservasi tanah pada lahan pertanaman singkong tidak berpengaruh nyata terhadap kehilangan unsur hara dan bahan organik. Perlakuan aplikasi pupuk organonitrofos tidak berpengaruh nyata terhadap kehilangan N-total, Ptersedia, K-dd, dan C-organik. Tidak ada pengaruh interaksi antara perlakuan tindakan konservasi tanah dan aplikasi pupuk organonitrofos terhadap N-total, P-tersedia, K-dd dan C-organik pada lahan pertanaman singkong.

\section{DAFTAR PUSTAKA}

Banuwa, I.S. 1994. Dinamika Aliran Permukaan dan Erosi Akibat Tindakan Konservasi Tanah pada Andosol Pangalengan Jawa Barat. Makalah. Institut Pertanian Bogor. Bogor. 9 hlm

Banuwa, I.S.2013.Erosi.Kencana Prenadamedia Group. Jakarta. $205 \mathrm{hlm}$

Henny H., K. Murtilaksono, N. Sinukaban, dan S.D. Tarigan. 2011. Erosi dan Kehilangan Hara pada Pertanaman Kentang dengan Beberapa Sistem Guludan pada Andisol di Hulu DAS Merao, Kabupaten Kerinci, Jambi.Jurnal Solum, 8 (2): 43-52.
Lidiasari E, Syafutri MI, dan Syaiful F. 2006. Influence of drying temperature difference on physical and chemical qualities of partially fermented cassava flour, Jurnal Ilmu-ilmu Pertanian Indonesia, 2006, vol. 8, pp. 141-146

Lingga, P. dan Marsono. 1999. Petunjuk Penggunaan Pupuk. Penebar Swadaya.Jakarta. 160 hlm.

Nugroho, S.G., Dermiyati, J. Lumbanraja, S.Triyono, H. Ismono, M.K Ningsih, dan F.Y Saputri. 2012. Inoculation Effect of $\mathrm{N}_{2}$ - Fixer and PSulobilizer into a Mixture of Fresh Manure and Phosphate Rock Formulatedas Organonitrofos Fertilizer on Bacterial and Fungal Populations. Journal of Tropical Soils, 18(1): 75-80

Pratiwi dan B.H. Narendra 2012. Pengaruh Penerapan Teknik Konservasi Tanah terhadap Pertumbuhan Pertanaman Mahoni (Swietenia macrophylla King) di Hutan Penelitian Carita, Jawa Barat. Jurnal Penelitian Hutan dan Konservasi Alam, 9(2): 139-150.

Soepardi, G. 1983. Sifat dan Ciri Tanah. Departemen Ilmu Tanah Fakultas Pertanian, IPB. Bogor. $591 \mathrm{hlm}$

Sutapradja, H. dan A.A. Ashandi. 1998. Pengaruh Arah Guludan, Mulsa, dan Tumpangsari terhadap Pertumbuhan dan Hasil Kentang serta Erosi di Dataran Tinggi Batur. Jurnal Hortikultura, 8(1): 1006-1013 